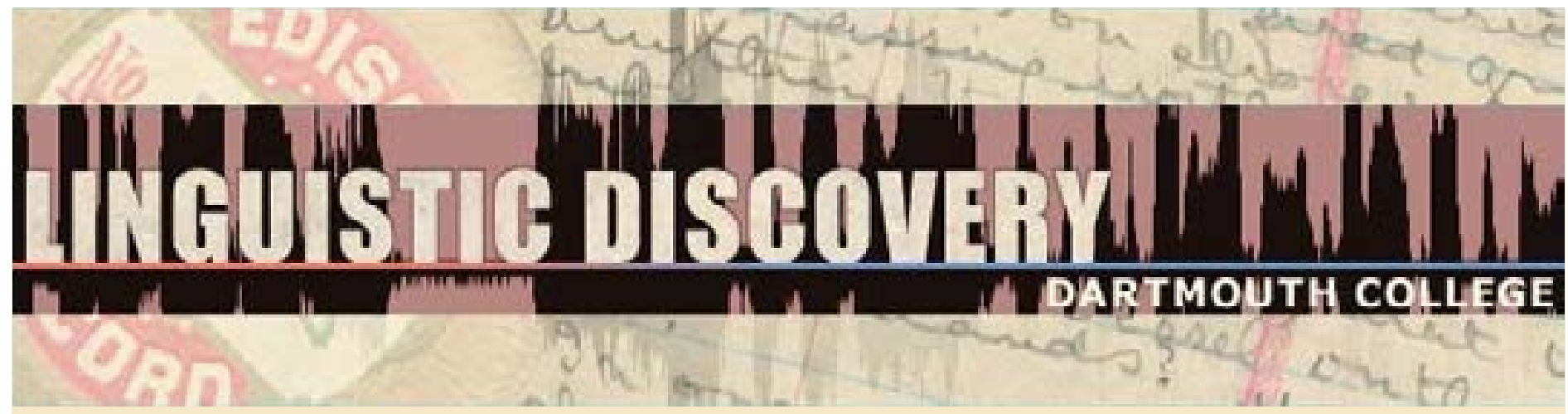

\begin{tabular}{|l|}
\hline Volume 10 \\
Issue 1 \\
2012 \\
\hline
\end{tabular}

\title{
Parataxis, Hypotaxis and Para- Hypotaxis in the Zamucoan Languages
}

Pier Marco Bertinetto \& Luca Ciucci

Scuola Normale Superiore, Pisa

doi: $10.1349 / P S 1.1537-0852 . A .404$

url: http://journals.dartmouth.edu/cgi-bin/WebObjects/ Journals.woa/1/xmlpage/1/article/404

Linguistic Discovery

Published by the Dartmouth College Library Copyright to this article is held by the authors. ISSN 1537-0852 linguistic-discovery.dartmouth.edu 


\section{Parataxis, Hypotaxis and Para-Hypotaxis in the Zamucoan Languages}

Pier Marco Bertinetto \& Luca Ciucci

Scuola Normale Superiore, Pisa

The term "para-hypotaxis" is commonly used by Romance linguists to refer to sentences containing a proleptic dependent clause, with the main clause introduced by a coordinator. It is thus an intermediate structure between parataxis and hypotaxis; it should not be confused, however, with seemingly analogous phenomena, such as co-subordination. Traditionally considered as an idiosyncratic feature of the Old Romance languages (as well as Biblical Hebrew, Greek and Latin), para-hypotaxis has recently been discovered in at least one modern, genetically unrelated language (Swahili). This paper shows - with illustrations mostly stemming from the Zamucoan family (Ayoreo and Chamacoco) - that it is also widespread in several languages of the Chaco Boreal. The possible functional justifications of this peculiar syntactic phenomenon are discussed. ${ }^{1}$

\section{Introduction}

The term para-hypotaxis (henceforth: $\mathbf{P}-\mathbf{H})$ was first introduced by Sorrento $(1929 ; 1950)$ and is still commonly used by Romance linguists. It designates sentences containing a proleptic dependent clause, with the main clause preceded by a coordinator, as in the following scheme (see also fn. 2):

$$
\text { SUB }+ \text { dependent-clause }+ \text { COORD }+ \text { main-clause }
$$

The proposal of P-H can be viewed as one of the first attempts to overcome the dychotomic conception of the parataxis / hypotaxis contrast. It is no wonder that the observation was made with reference to Old Romance texts, due to the relatively high frequency of this kind of structure in all literary genres until the $15^{\text {th }}$ century, with a slightly different timing in the individual languages. Here are examples from Old French (2), Old Occitan (3), Old Portuguese (4), Old Spanish (5) and Old Italian (6) texts:

(2) Old French (Aucassin et Nicolette 18,10)

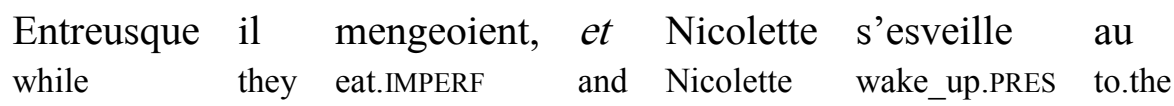

\footnotetext{
${ }^{1}$ The authors wish to thank Luca Pesini for providing useful pieces of information; Margherita Farina for fruitful discussion on Biblical Hebrew and for suggesting example (8); Lara Nicolini for checking (and integrating) example (7); Anna Alexandrova for the Ancient Slavonic reference in fn.11; Alain Fabre and Pedro Viegas Barros for pointing out the data in examples (39-42); Manfred Ringmacher and Pieter Seuren for pointing out a number of inaccuracies.

The transcriptions of the Ayoreo and Chamacoco examples follow the orthography established by the Evangelical missionaries. The conventions are in both cases inspired by the Castilian orthography. Although this has no direct consequences for the understanding of the present paper, the interested reader can find the relevant indications in Higham et al. (2000) and Ulrich \& Ulrich (2000b). A summary of these conventions is to be found in Bertinetto (2009) and Ciucci (2010:2).
} 
$\begin{array}{lll}\text { cri } & \text { des } & \text { oisiax } \ldots \\ \text { cry } & \text { of.the } & \text { birds }\end{array}$

'While they were eating, Nicolette woke up to the birds'cries ...'

(3) Old Occitan (Chanson de la croisade albigeoise, Bartsch-Koschwitz, Chrestomathie Provençale, $1904^{6}$, p. 203)

E si venoi-lh Frances, que vulhan asautar, $e$ nos ab las and if come-3P French who want.3P assault and we with the

balestas es far-em tot-z nafrar

arbalests them do.FUT-3P all-P wound.INF

'And if the French people come and want to assault us, we shall wound them with the arbalests.'

(4) Old Portuguese (Liederbuch der Königs Denis von Portugal, Lang, Halle, 1894, 2722)

$\mathrm{E}$ quand el disse: ir-me quer eu deitar, and when he say.PRET-3P go-INF-1S want.1S 1s lie_down.INF

e dix'eu: bo-a ventura ajad-es

and say.PRET-3P good.F fortune accomplish.SUBJ-2P

'And when he said: «I want to go to lie down», I said: «Good luck to you».'

(5) Old Spanish (El libro dela Caza, G. Baist (ed.), Halle, 1880, 7, 29)

quando los can-es lleg-an a la grua quanto bien la

when DET.MP dog-P come-3P to ART.FS crane how_much well 3FS

tom-an en guardar los falcon-es qu' eles non faz-en ningun

take-3P in check.INF ART.MP falcon-P SUB 3MP NEG do.SUBJ-3P no

mal, e es muy marabillos-a cosa

harm and Is very wonderful.F thing

'When the dogs reach the crane, it is wonderful (to observe) how carefully they protect her from the falcons, so that they do not do any harm to it'

(6) Old Italian (Dante Alighieri, Inf. 30.115)

$\begin{array}{lllllll}\text { S' } & \text { io } & \text { dissi } & \text { il } & \text { falso, } & e & \text { tu } \\ \text { If } & \text { 1s } & \text { say.1S.PAST.PERF } & \text { DET.MS } & \text { false-MS } & \text { COORD } & 2 \mathrm{~S}\end{array}$

falsasti il conio

alter-2S.PAST.PERF DET.MS minting_die-MS

'If I said something false, you (did worse, for you) altered the minting die'

P-H was fairly common in Late Latin, but the first examples date from much earlier times (7). 
This is noteworthy, for it discards the diachronic hypothesis based on the influence of Hebrew on Late Latin via Bible translations (see $\S 5$, especially fn. 11). As it happens, this syntactic structure is not only very old, but liable to arise in completely unrelated languages. ${ }^{2}$ The influence of Late Latin on the early Romance languages is, on the other hand, quite likely, just as it is an established fact that Bible Hebrew presented frequent examples of P-H (8).

(7) Latin (Plautus, Ep. 217)

quom ad portam veni-o, atque ego illam $\quad$ illi

when at gate-ACC.FS come.PRES.IND-1S COORD 1S.NOM DEM-ACC.FS LOC

vide-o praestolarier et cum ea tibicinae

see.PRES.IND-1s wait_for.INF COORD with 3.ABL.FS flute_player-NOM.FP

ibant quattuor

gO.PAST.IMPERF-3P four

'When I arrive at the gate, full of impatience, I see her there coming, accompanied by four flute players'

(8) Hebrew (Bible, 1 Sam 11, 3)

wo-'im-'ên môšî̀a 'etånû wo-yåsånû 'eleykå

and-if-there_is_not saving/delivering.PT 1P.DO and-go_out.FT.1P towards_you

'And if there is none to deliver us, we will come out to thee'

P-H was considered (possibly only implicitly) to be an areal and fairly archaic feature. Recent research has however revealed this use in modern languages, such as Swahili (Rebuschi 2001). Basque has also been indicated as a possible candidate (Rotaetxe 2006), but on close examination it turns out that this is probably not the case. ${ }^{3}$ As shown here for the first time, P-H is a pervasive feature in the Zamucoan languages. It thus appears that $\mathrm{P}-\mathrm{H}$ is neither

${ }^{2}$ It should be noted that P-H can also arise when the proleptic dependent clause involves a non-finite verb form with no subordinator, as in the following example from the early $14^{\text {th }}$ century. This detail will be no further discussed in this paper.

(i) Italian (Dante Alighieri, Vita Nuova, ch. 24, 1)

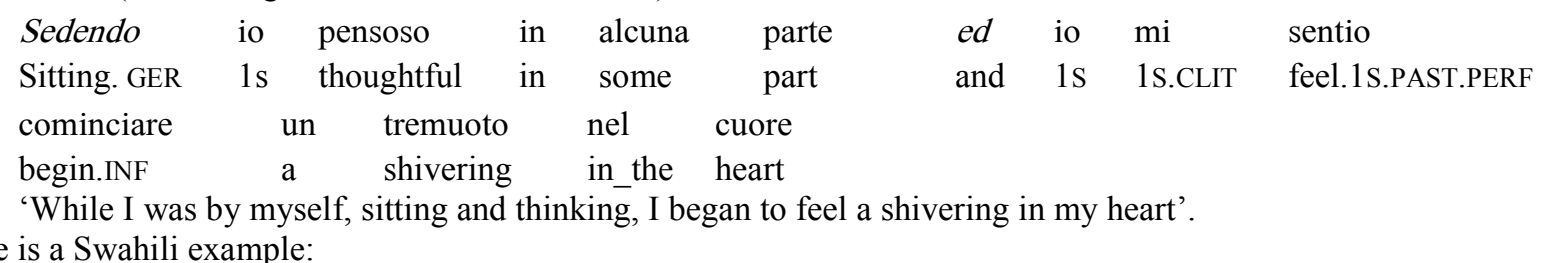

${ }^{3}$ Here is a Swahili example:

(i) Swahili (Rebuschi 2001, ex. [38])

\begin{tabular}{|c|c|c|c|c|c|c|c|}
\hline Mtu & ye & yote & akitaka & kunifuata & na & ajikane & mwenyewe \\
\hline $\operatorname{man}$ & all & if & 3s.want & 1s.follow & and & 3s.deny.SUBJ & 3.RFL \\
\hline
\end{tabular}

'Should anyone want to follow me, he should renounce to himself'.

As for Basque, Rotaetxe (2006) convincingly argues that the constructions involving the enclitic -eta, despite homophony with the (non-enclitic) coordinator eta 'and', should not be considered as cases of P-H. In particular: (a) -eta always precedes an interclausal pause, while eta follows it; (b) -eta has a temporal/causal meaning, while true para-hypotactic coordinators can appear in a diverse range of syntactic structures. 
geographically nor diachronically restricted, although its presence has admittedly not been shown to be widespread. It is important to observe, at any rate, that it can independently develop in unrelated languages. Hence, although its diffusion (for all we know) is not very large, one should regard it as a universally available and autonomously arising syntactic device.

Indeed, contrary to the received opinion, P-H latently exists in Modern Italian, as the following example (heard by one of the present authors) proves: ${ }^{4}$

(9) Italian [spontaneous utterance by a Florentine speaker]

$\begin{array}{llllll}\text { Quando } & \mathrm{i} & \text { fatt-i } & \text { divent-ano } & \text { personal-i, } & e \\ \text { when } & \text { DET.MP } & \text { thing.MP } & \text { become-3P.PRES.IND } & \text { personal-MP } & \text { COORD }\end{array}$

[s:]ono difficil-i da gest-ire

be.3P.PRES.IND hard-MP to deal_with-INF

'When things become personal, they are hard to deal with'

A point worth further study is the frequency of occurrence of para-hypotactic constructions. Even during the periods of most intense usage in the Romance languages, this syntactic strategy was never used systematically. Besides, no analysis to date has been targeted to ascertain its relative frequency with the various types of proleptic dependent clause. ${ }^{5}$ This issue will be addressed in the present paper.

The general topic of the parataxis/hypotaxis continuum, ${ }^{6}$ on the other hand, will not be addressed here. It will suffice here to observe that the structural configuration corresponding to $\mathrm{P}-\mathrm{H}$ is not mentioned in the elaborate syntactic model by Foley \& Van Valin (1984), who introduced the notion of "co-subordination". Despite formal equivalence (only differing in the reference language, i.e. Latin instead of Greek), the latter term should not be confused with P-H. An obvious reason to keep these theoretical constructs apart is that, according to Foley \& Van Valin, co-subordination may be found at three structural levels: nucleus, core and periphery. The only meaningful comparison with $\mathrm{P}-\mathrm{H}$ could be done at the last level, but even there it immediately appears that $\mathrm{P}-\mathrm{H}$ and co-subordination do not coincide. The latter notion was applied, for instance, to the so-called "clause chaining", to be found in the narratives of many New Guinea and Australia languages, an ostensibly different type of syntactic construction.

Similarly, Rebuschi (2001) introduced the seemingly equivalent notion of "co-jonction", but here again - although he did mention $\mathrm{P}-\mathrm{H}$ - the new term defines a specific kind of structural configuration (in practice, co-jonction turns out to be a hyperonym of $\mathrm{P}-\mathrm{H}$ ). $\mathrm{P}-\mathrm{H}$ is also completely absent from the elaborate parataxis/hypotaxis continuum built by Lehmann (1988) and from the multivariate approach developed by Bickel (2011), which finely articulates the coordination / subordination contrast along a number of variables (among which: illocutionary scope, tense scope, tense marking, finiteness, focus marking, etc.).

This shows the marginal status of $\mathrm{P}-\mathrm{H}$ within typological syntax: a good reason to carefully consider the case. Two hypotheses suggest themselves: either $\mathrm{P}-\mathrm{H}$ is a universally available but very sparsely attested phenomenon, or its diffusion is larger than so far supposed, except that not

\footnotetext{
${ }^{4}$ The phonosyntactic doubling of the copula's initial consonant indicates that the preceding word is indeed the coordinator 'and', rather than the Florentine Italian third plural pronoun.

${ }^{5} \mathrm{As}$ far as Italian is concerned, this feature is currently under examination in the doctoral dissertation of Luca Pesini.

${ }^{6}$ The word 'continuum' is not appropriate in this case, for the transitions between the various intermediate types are discrete and unevenly spaced.
} 
enough attention has been devoted to it.

\section{The Zamucoan Languages}

The Zamuco family consists nowadays of only two languages: Ayoreo and Chamacoco. It was presumably confined to a fairly small population even in the past and the number of languages must not have been significantly larger than it is now. The ethnonym ayorei [ajo'sej] MS (ayoréode MP, ayoré FS, ayoredie FP) means '(real) person', as opposed to the outsiders, just as the word ishiro [i'ciro] (as the Chamacoco call themselves) does (ishirc MS, ishiro MP; both forms are often reduced to their root ishir). The Ayoreo (ca. 3800 people according to Ethnologue or 4500 according to Fabre 2007) are quite remarkable in that they are the only ethnic group in the Chaco area that has not yet entirely surrendered to Western culture. Although most of them now live in permanent communities originally built around a mission in rural environments (with the exception of a settlement in Santa Cruz de la Sierra), there are still two or three small, virtually non-contacted groups continuing the traditional nomadic life in North-East Paraguay. The Ayoreos' level of social integration within the surrounding culture is, altogether, rather low, although bilingualism is increasing. The Chamacoco (between 1600 and 1800 people) are, in comparison, somewhat more integrated, although the majority of them still live in rural communities on their ancestral land. It is to be noted that many Chamacocos have at least a passive competence of Guaraní, which makes they trilingual.

The Ayoreo's traditional territory used to extend (southward) from the area East of Santa Cruz de la Sierra in Bolivia (Gran Chiquitanía) to the Northern Paraguayan Chaco and (eastward) from Río Grande to Río Paraguay. The population is more or less equally spread out between Bolivia and Paraguay. The Chamacoco used to occupy - and most of them still live in the easternmost portion of the Paraguayan Northern Chaco, bordering the river Paraguay. There are reasons to suppose, based on anthropological findings, that these tribes moved to the Chaco area from the inner Amazonian region, presumably under pressure from hostile populations (Fischermann 1988). Due to nomadic life and the need to compete for natural resources, they used to have unfriendly relations with all their neighbors and even among themselves. Indeed, they were regarded (especially the Ayoreo) as frightful and fierce warriors.

The Chamacoco started to have peaceful relationships with the Hispano-American culture well before the end of the XIX century, whereas the Ayoreos began to surrender little before the middle of the last century, due to evangelical missionaries from the United States. The contact history is, however, much longer (Combès 2009). Towards the end of the XVII century, the Jesuits managed to bring different ethnic and linguistic groups into fortified missions in the Chiquitanía. In 1724 the mission of San Ignacio de Samucos (i.e. Zamucos) was founded (supposedly in the Bolivian Chaco), but it had to be abruptly abandoned in 1745 and its exact location remains unknown. The Jesuit Ignace Chomé - born in what was then the French Flanders - was there until the end and wrote a very valuable grammar concerning a language quite close to Modern Ayoreo, but interestingly with some features reminding more of Chamacoco than of Ayoreo (cf. Chomé in the references).

From the typological point of view, the Zamucoan languages are fusional and present an SVO basic word-order. One should also mention that there exist two different dialects of Chamacoco: Ebitoso (or fbitoso) and Tumarãho. The data reported in this paper refer to the first variety, spoken by the vast majority of the Chamacoco people. 


\section{Zamucoan Connectors}

It is not easy to assess how deeply rooted the Zamuco hypotactic structures are. There are however hints that they must not have been fully developed until perhaps recently. The hints are of two sorts.

On the one hand, Ayoreo presents a relative shortage of subordinators, which suggests a relatively simple syntactic organization. Since the language also exhibits residual (i.e., lexically idiosyncratic) vestiges of what Bertinetto (2009) calls the "verbal noun" - typically exploited in interrogative sentences - one might assume that some kind of converbal structures might have been used on a larger scale in the past, possibly reducing the need for subordinators.

On the other hand, although Chamacoco presents a larger variety of subordinators, it includes quite a number of clearly imported ones (see the bold characters in Table 1). This points to severe syntactic contamination. Such loans from Castilian do not prove that the corresponding hypotactic structures did not previously exist; however, if they did, one might assume that their frequency of use was lower.

\begin{tabular}{|c|c|c|}
\hline & AYOREO & CHAMACOCO \\
\hline \multicolumn{3}{|c|}{ COORDINATORS } \\
\hline Conjunctive & $\begin{array}{l}\text { (e)nga } \\
\text { [only interclausal] }\end{array}$ & $h n$; ich [only VP] \\
\hline Adversative & $m u$ & mahn / per [Sp. pero] \\
\hline Disjunctive & jeonga, poga & $\boldsymbol{o}[$ Sp. o] (kimïji) \\
\hline Negative & & hnii $[\mathrm{Sp} . n i]$ \\
\hline \multicolumn{3}{|c|}{ SUBORDINATORS } \\
\hline Relative & uje & uje \\
\hline Causal & uje & $\begin{array}{l}\text { pork }[\mathrm{Sp} \text {. porque]; } \\
\text { yejï [arcaic] }\end{array}$ \\
\hline when-clause & uje & $\begin{array}{l}\text { uje / (uje) ehn; } \\
\text { namiji [prospective] }\end{array}$ \\
\hline after-clause & uje e / $\mathrm{N}+$ quigade & $\begin{array}{l}\text { (depwe [Sp. después]) } \\
\text { uje; } \\
\text { namijit [prospective] }\end{array}$ \\
\hline until-clause & jeaja & $\begin{array}{l}\text { nehech / } \\
\text { a(s)ta [Sp. hasta] uje }\end{array}$ \\
\hline before-clause & uje cama & $\begin{array}{l}\text { uje (ehn) ya(ha)paa / } \\
\text { ehn ya(ha)paa / } \\
\text { nakaha / jenehe / } \\
\text { ante [Sp. antes] uje }\end{array}$ \\
\hline since-clause & - & shiyehe (uje) \\
\hline Final & ujetiga & par [Sp.para] (uje) \\
\hline Hypothetical & ujetiga & $\begin{array}{l}\text { uje / kimijiz } \\
\text { [real hypoth.]; } \\
\text { kirêhe / kêhe } \\
\text { [contrafact.] }\end{array}$ \\
\hline Concessive & (ujetiga...) maringa & ahni \\
\hline
\end{tabular}

Table 1: Zamucoan connectors. Slashes separate alternative forms; parentheses delimit optional components; bold character indicate loans from Castilian. 
The next two sections present a non-exhaustive list of examples illustrating the use of the Zamucoan connectors in relation to the main types of coordinating and subordinating constructions. The relevant items are italicized for ease of the reader.

\subsection{Coordinators}

We begin with conjunctive NP-coordination, which in Ayoreo is mostly obtained via asyndeton (10) or - less frequently and subject to semantic restrictions - via a comitative construction based on the verb 'to accompany'. Chamacoco may adopt the asyndeton strategy as in (11), but can also make use of an explicit connector as in (12).

(10) Ayoreo [QCCB, count n. 2]

Tito, cojño-i ore ch-isõre

Tito gringo-MS 3P 3-go_for_a_walk

'Tito and the gringo went for a walk'

(11) Chamacoco [Ciucci, field-work]

Yok, waa p-ihyã-ta Sara oy-uko oy-omsehe katsimo

1SG DET.FS 1S-friend-FS Sara 1PE-go 1PE-enter catechism

'I and my friend Sara begin to go to catechism'

(12) Chamacoco [Ciucci, field-work]

Leki wishi õ akiliy-o hn pap akiliy-o $h n$

grandfather poor.MP 3P 3.teaching-MP COORD 1s.father 3.teaching- MP COORD

Porrosh-t akiliy-o ich de yoo

God-MS 3.teaching EMPH EXIST 1s

'The poor grandfathers' teaching, my father's teaching and God's teaching are in me'

With conjunctive VP-coordination, Ayoreo exploits a specific connector (13), while Chamacoco can choose between the two autoctonous coordinators shown in Table 1 (14-15). One of them $(h n)$ also features in (12) as NP-coordinator. The other (ich), by contrast, may also have the function of an emphatic marker enhancing the meaning of the following word, as in (12) and (16). The same holds for adversative VP-coordination: Ayoreo (see again example [13]) has only one possibility, while Chamacoco has two options, one of them consisting of a Castilian loan (17).

(13) Ayoreo $[\mathrm{QCCB}]$

D-aye $\quad$ ch-icho $=$ po $=$ rase rĩ, $m u$ ch-icho ejo-i enga ch-icho Tito

3-father 3-shoot=also=MOD ITER but 3-shoot 3.side-MS COORD 3-shoot Tito

'His father tried to shoot once more, but he missed the target and hit Tito' 
(14) Chamacoco [Ciucci, field-work]

Oy-ish kojachi=ke ich oy-iyãha pehle hõr oskõr

1PE-reach hill=PAST COORD 1PE-seek pehle_fruit.FP with oskôr_fruit.FP

'We meet on the hill and collect two types of fruit'

(15) Chamacoco [Ciucci, field-work]

S-ahmũru ishir-rza apibiti-t $=$ ni $\quad h n \quad$ asa

3-love indigenous-FS young_woman-FS=PAST COORD DET.FS

ishir-rza $\quad$ apibiti-ta $\quad$ s-ahmũr $=$ po

indigenous-FS young_girl-FS 3-love=also

'(He) loved that indigenous young woman and that indigenous young woman also loved (him)'

(16) Chamacoco [Ciucci, field-work]
a. Ese poho-ch wis
b. Ese poho-ch ich wis
DET.MS dog-MS black
DET.MS dog-MS EMPH black

a. 'That dog is black' / b. 'That dog is so black'

(17) Chamacoco [Ciucci, field-work]

Ẽhe, p-iji-ta, bu; per abey owa

Yes 1S-daughter-Fs 2s.go but 2s.be_careful 2s

'Yes, my daughter, go but be careful!'

The disjunctive and negative coordinators must be recent innovations. Chamacoco exploits two obvious loans from Castilian (cf. Table 1). Ayoreo lacks any negative coordinator, and only presents the disjunctive one (18).

(18) Ayoreo [Saberes y conocimientos del pueblo Ayoreo. Programa de Educación Intercultural Bilingüe de Tierras Bajas. PRIB-TB, Santa Cruz 2008]

Uje p-ique coño-ne ome doc-oji ute enga e

SUB NPS-hitting white.man-MP ADPOS NPS-bow.MS that COORD already

puyaque, jeonga p-ique caratai ome, jecute puyaque

sacred.BF COORD NPS-hitting jaguar ADPOS then sacred.BF

ome cheque-die Jeta oe ch-isa

ADPOS woman-FP COMP 3P 3-take

'When one kills a gringo with the bow, it immediately becomes a taboo, or (when) one kills with it a jaguar, it is then forbidden for the women to take it up.' 


\subsection{Subordinators}

For lack of space, not all syntactic structures listed in Table 1 will be illustrated here. One thing that Table 1 clearly points out is the pervasive presence of the connector uje (Ay. [uhe], Ch. [uxe]), which shows a sizeable degree of semantic flexibility. This is especially evident in Ayoreo. Lack of semantic specialization is not, in and of itself, conclusive proof that hypotaxis has only recently been introduced, but it certainly indicates that the language has not yet given rise to an elaborate range of syntactic-rhetorical possibilities. In Italian, for instance, the connector che [ke] can be used to introduce both a relative and a causal clause, although the latter option sounds old-fashioned. Similarly, in German, wenn [ven] can introduce a when-clause as well as a hypothetical protasis. Both Italian and German have, however, other options at their disposal, while this is not always the case in the Zamucoan languages, and the presence of loans in Chamacoco substantially confirms the described picture.

One notable feature of Ayoreo is the neat division of labor between uje and ujetiga, mirroring the realis / irrealis divide (Bertinetto 2009). This is further proved by the use of the irrealis mood in hypothetical and final clauses, which is especially mandatory in the former case. As for before-clauses, both Ayoreo and Chamacoco make use of the same structure, which translates in English as 'when not yet' (Ay. uje cama, Ch. uje (ehn) yahpaa). Admittedly, the parallelism between the two languages seems to highlight a native feature. This might suggest, contrary to what was noted above, that this idiosyncratic hypotactic structure is sufficiently old to show up in both languages. However, one could also interpret this as a spontaneously emerging response to the externally induced need to create a new type of hypotactic structure, by exploiting the presence in both languages of the (definitely autochthonous) negative adverbs cama and yahpaa. ${ }^{7}$ The latter hypothesis is further supported by the treatment of after-clauses. In Ayoreo, they are expressed by uje in its temporal meaning ('when') in combination with the adverb $e$, which can be roughly translated as 'already'. This appears to be a clever use of previously existing lexical tools. Significantly, Chamacoco uses in this case the bare uje (or namiji in prospective clauses), or a hybrid connector consisting of combining the loan depwe (cf. Cast. después) with uje.

Sentence (19a) is an example of Ayoreo relative clause. It should be noted that this language also presents what one might wish to define as "implicit relative clauses", as illustrated in (19b). To understand this, one should keep in mind that Ayoreo nominals come in two forms: 'full' and 'base' form (Bertinetto 2009; in this paper's glosses, only the latter is explicitly indicated, namely as BF). As (19b) shows, the base form typically has predicative import, so that in the relevant cases it can be the equivalent of a relative clause.

$$
\begin{aligned}
& \text { Ayoreo [Bertinetto, field-work] } \\
& \text { Y-ajire disi uje quena } \\
& \text { 1-look_at child.MS SUB 3.run } \\
& \text { 'I look at a/the child who runs' }
\end{aligned}
$$

\footnotetext{
${ }^{7}$ In both cases the first element ostensibly coincides with one possible form of the negation ( $c a$ in Ayoreo, ye in Chamacoco).
} 
(19b)

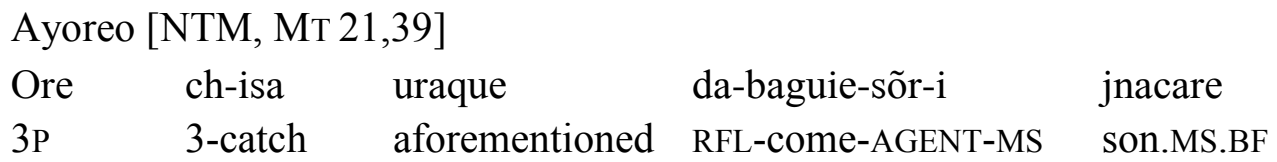

'They caught the son, his envoy' [= his-coming-up, (who was) the son]

Sentences (20-21) illustrate a temporal / causal clause. This possible ambiguity confirms the polyfunctionality of the Zamucoan connector uje, which indeed in (21) could also be read as a hypothetical connector. The last option is not available to Ayoreo, for - as noted above - the connector ujetiga must be selected in irrealis contexts. This is illustrated in (22), while (23) exhibits an alternative strategy available to Chamacoco. Crucially, these examples bring us back to the focus of this paper, for the proleptic dependent clause creates the conditions for P-H to apply; indeed, the main clause is in each case introduced by a coordinator (italicized for ease of the reader).

(20) Ayoreo [NTM, Mt 2,10]

Uje ore ch-imo guedo uje cha, enga guedo

SUB 3P 3-see star.FS SUB 3.stop COORD

iraja-sõr-one ore nina raque

know-AGENT-MP 3P 3.rejoice RFL

'When they saw that the star stopped, the wise men rejoyced'

(21) Chamacoco [Ciucci, field-work]

Uje ye t-uu_leeych, ich ese aahn-t s-erz yoo

SUB NEG 1S-fight COORD DEM.MS evil_spirit-MS 3-win $1 \mathrm{~s}$

'When/if I don't fight, that evil spirit will defeat me'

(22) Ayoreo [Bertinetto, field-work]

Ujetiga Jate di $=$ rase $\quad n g a, \quad$ ch-isi $=$ rase $\quad$ yogu $=\mathrm{iji} \quad$ cucha-rique

SUB Jate 3.arrive $=$ MOD COORD 3-give $=$ MOD $1 \mathrm{P}=$ LOC thing-MS.IF

'If Jate arrived, he would give us something'

(23) Chamacoco [Ciucci, field-work]

Kẽhe, uu like ishir lishi sẽhe, teehe,

If DET.MS this indigenous.MS poor.MS want INTERJ

s-ohnimichi=ke, $h n$ uhu oy-ihyer ire

3.IRLS-get_off=PAST COORD 2S.CAUS 1PE-arrest 3s

'If the indigenous had wanted to get off (the bus), you would have made us arrest him'

Similarly, the following examples illustrate final (24) and concessive (25-26) proleptic clauses, once again followed by a para-hypotactic connector. ${ }^{8}$ In example (25), the concessive protasis is marked by ujetiga ... maringa, where the first element is optional. Apparently, the Ayoreo

\footnotetext{
${ }^{8}$ The examples with an adversative para-hypotactic coordinator are less frequent than those with a conjunctive coordinator, but nevertheless well-attested. Cf. Mazzoleni (2002) for this type of construction in Old Italian.
} 
concessive structure, besides involving a clause-final rather than a clause-initial connector (maringa), does not involve P-H. However, maringa, besides continuing the Old Zamuco connector mari cited in Chomé's grammar, ostensibly contains enga. Since modern Ayoreo speakers do not understand the word mari, we propose that the systematic fusion of the old subordinator mari with the para-hypotactic coordinator enga has reached the stage of full univerbation in maringa.

\begin{tabular}{|c|c|c|c|c|c|c|}
\hline \multicolumn{7}{|c|}{ Ayoreo [QCCB] } \\
\hline Dupade & $\mathrm{e}$ & e & ingome & ua & ujetiga & ataja \\
\hline God & EMPH & already & 1.tell-ADPOS & 2 & SUB & 2.help.IRLS \\
\hline ujetiga & $y$-ijnime & dope & & e & jne & \\
\hline SUB & 1-catch & (type & of)_fish.FS & hat & afterwards & \\
\hline
\end{tabular}

(25) Ayoreo [PREACHERS]

Ujetiga a-dute cucha ajmacaca-rique maringa je ca

SUB 2S.IRLS-listen thing.MS.BF ill_fated-MS.IF although MOD NEG

a-todo cucha ajmamacar-ode

2S.IRLS-fear thing.MS.BF ill_fated-MP

'Even though you might hear threats, do not be afraid of them'

(26) Chamacoco [Ulrich \& Ulrich 1992:11]

Ahni a-sew o-bi-yo = ho wir shakir par e-kwẽr

Although 2s-take NPS-work-MP=APPL DET.P field.FP SUB 2s-seed

wir jõro per shì ye latik tokole

DET.P plant.FP but yet NEG nothing 3.get_out

'Although you work in the fields to seed the plants, nothing has so far grown'

\section{Subordination, Genre and Type of Dependent Clause}

In Old Romance, the presence of $\mathrm{P}-\mathrm{H}$ was pervasive but not without exceptions. It is thus interesting to check the situation in the Zamucoan languages, taking into account two sorts of variables: textual genre and type of dependent clause.

Table 2 depicts the situation with respect to the first variable, presenting the distribution of dependent clauses as a function of the total number of sentences. As the reader may note, there is some approximation as for the number of sentences in oral texts, for the recordings do not always make clear where exactly a sentence ends. In some cases, one is in doubt whether a given pause marks a break between two sentences, or simply a boundary between two clauses within one and the same sentence. Obviously, this kind of doubt does not emerge with written texts.

The written texts stem from the Bible translations (NTM; Ulrich \& Ulrich 2000a). The sources of the oral ones were the following. For Ayoreo: three short religious sermons available on the web (Preachers), two tales collected by one of the present authors from the informant Dijaide, 
and excerpts from the memories of the old chief Samane, kindly made available by by APCOBBolivia, Santa Cruz de la Sierra, an ONG directed by Jürgen Riester. ${ }^{9}$ For Chamacoco: 18 narratives recorded by one of the present authors with speakers native of Puerto Diana and Fuerte Olimpo.

\begin{tabular}{|l|c|c|}
\hline \multicolumn{1}{|c|}{ AYOREO } & Oral texts & Bible translation \\
\hline N of sentences & ca. 400 & 633 \\
\hline depend. Clauses & 80 & 408 \\
\hline Ratio & $5 / 1$ & $1.5 / 1$ \\
\hline $\begin{array}{c}\text { Disaggregation } \\
\text { of the oral texts }\end{array}$ & Preachers & Samane +Dijaide \\
\hline N of sentences & ca. 130 & 280 \\
\hline depend. Clauses & 60 & 39 \\
\hline Ratio & $2 / 1$ & $7 / 1$ \\
\hline \multicolumn{1}{|c|}{ CHAMACOCO } & Oral texts & Bible translation \\
\hline N of sentences & 616 & 1587 \\
\hline depend. Clauses & 123 & 719 \\
\hline Ratio & $5.01 / 1$ & $2.2 / 1$ \\
\hline
\end{tabular}

Table 2: Density of dependent clauses as a function of written vs. oral texts.

Among dependent clauses are subordinated clauses, completives and relatives, although not all of them are a trigger for P-H. Unsurprisingly, in both languages the ratio between the overall sentence number and the dependent clauses is higher in oral than in written texts. Evidently, the former contain a significantly smaller number of dependent clauses. Two causes converge towards this result. First, the natural tendency to reduce the syntactic-rhetorical complexity of oral as opposed to written texts. Second, the possible - indeed likely - influence of Western linguistic habits introduced by the translators, as well as induced by the original model (which was, for both Ayoreo and Chamacoco, some English version of the Bible). Significantly, in the written texts of both languages the ratio turns out to be the same. As for the oral texts, a notable distinction should be made for Ayoreo between the Preachers' productions and those of the two old informants Samane and Dijaide. As Table 2 shows, the former productions present a much higher density of dependent clauses. Most probably, the Preachers' texts were first written and then, if not directly read, possibly repeatedly rehearsed. This is compatible with their notably high speech rate.

Table 3 shows the most relevant data as distinguished by type of dependent clause. The count is only based on the oral texts, for - as just noted - they appear to be much more immune to Western contamination. In order to obtain more robust observations, only the most frequent types of dependent clause are reported. For instance, no data are provided for the relatively rare (and almost always proleptic) concessive clauses. As it happens, not all types are equally prone to prolepsis. With causal and final clauses, analepsis is definitely preferred. The reason for this is pragmatic: it is more natural for an explanatory statement to follow its premise. With temporal when-clauses, by contrast, there is no order preference. Finally, with hypothetical clauses the protasis tends most naturally to precede the apodosis. Actually, judging from Table 3, the number of Chamacoco hypothetical clauses in the corpus appears to be vanishingly small.

\footnotetext{
${ }^{9}$ These recordings are part of the project: "Recuperar la Memoria Oral de los Indígenas".
} 
However, this merely depends on the virtual impossibility to distinguish them from whenclauses. As a consequence, the number of proleptic when-clauses appears to be inflated.

\begin{tabular}{|c|c|c|}
\hline oral texts & AYOREO & CHAMACOCO \\
\hline proleptic causal clauses & 2 & 0 \\
\hline analeptic causal clauses & 11 & 13 \\
\hline proleptic final clauses & 3 & 0 \\
\hline analeptic final clauses & 8 & 30 \\
\hline proleptic when-clauses & 9 & 28 \\
\hline analeptic when-clauses & 8 & 3 \\
\hline proleptic hypothetical clauses & 9 & 3 \\
\hline analeptic hypothetical clauses & 4 & 0 \\
\hline
\end{tabular}

Table 3: Number of proleptic vs. analeptic dependent clauses as a function of syntactic structure type.

Whatever the preferential order of dependent and main clauses, the remarkable fact is that in Ayoreo $77 \%$ of the proleptic dependent clauses involve $\mathrm{P}-\mathrm{H}$, with a coordinator introducing the main clause (but see below for further elaboration of this datum). In Chamacoco this percentage is even higher: $84 \%$. It should be remarked that $\mathrm{P}-\mathrm{H}$ is also very frequent in the Bible translations of both languages: in Chamacoco, in particular, the percentage reaches up to $96 \%$. This is crucial, for it demonstrates that, despite inevitable Western influence, the autoctonous syntactic features were strong enough to impose their own rights. ${ }^{10}$

\section{How Did P-H Evolve?}

The traditional explanations offered for $\mathrm{P}-\mathrm{H}$ are the following two, both having their own problems:

(A) P-H originates in spontaneous colloquial speech as an attempt to reduce the complexity of the syntactic structure (Sorrento 1950).

(B) P-H in Old Romance was inspired by classical models: Biblical Hebrew, Greek, Latin (Pasquali 1929).

To (A), one can oppose a number of arguments. First, as noted by La Fauci (2007), coordination is not necessarily simple. As a matter of fact, Friedman \& Costa (2010) offer psycholinguistic evidence that the processing of coordinated clauses presents variable degrees of difficulty, depending on the coordinated constituents and their degree of embedding. Second, although it is now widely accepted that there are several intermediate possibilities between coordination and subordination, nobody seems to directly correlate the existence of such intermediate structures with a syntactic complexity scale, whose construction is far from obvious. Third, inspection of Old Romance texts shows that P-H was pervasive in all kinds of written texts, even the most remote from the colloquial register.

The objections to be raised against (B) are even more straightforward. First, P-H exists in languages like Swahili, Ayoreo and Chamacoco (and others: see below), obviously immune from

\footnotetext{
${ }^{10}$ With special regard to $\mathrm{P}-\mathrm{H}$, it should be noted that at the time of first contact with the Zamuco tribes, Castilian had virtually lost any trace of P-H. One must thus exclude any Romance influence in this respect.
} 
any influence from Hebrew, Greek and Latin. ${ }^{11}$ Second and foremost, even supposing that this were the case, where did the Classical languages get inspiration from? Rather than providing an explanation, hypothesis (B) is just a way to push the problem further back into the past.

\subsection{Syntactic and Pragmatic Explanations}

A number of alternative explanations have been proposed in more recent times. These may be divided into two main branches: syntactic and pragmatic. They will be considered in this order.

The syntactic explanations are based on the attempt to individuate intermediate structures bridging the gap between parataxis and hypotaxis (Abeille \& Borsley 2006). The most obvious candidates are correlative constructions (27) and implicit hypotheticals (28). In both examples, one can easily detect a hidden hypothetical structure, as explicitly illustrated in (28a', 28b'). Similarly, one might perceive an implicit final construction as in (28b"). It is thus not unreasonable to surmise that, at a given point, the speakers might create a sort of fusion among these hiddenly related syntactic types, giving rise to fully-fledged $\mathrm{P}-\mathrm{H}$.

Italian [Dante Alighieri, Purg. 4.90]
$e \quad$ quant' om più va
COORD EMPH one more go.3S.PRES.IND
'The more one goes up, the less it hurts'

(28a) You say another word and I leave

(28a') If you say another word, I leave

(28b) Allow me the time and I'll do X

(28b') If you allow me the time, I'll do X

(28b") Allow me the time in order for me to do X

The pragmatic explanations insist, instead, on the textual function supposedly attached to parahypotactic structures (Durante 1982; Wehr 1984; Torterat 2000; various authors in Salvi \& Renzi

\footnotetext{
${ }^{11}$ It is beyond the scope of the present paper to address the situation in these languages (but see Pasquali 1929). Suffice it to say that both Homeric Greek and Old Latin present some unmistakable examples of P-H, although admittedly rather rare. In both cases, however, there seems to be a gap until the Bible translations, when P-H reappears and acquires momentum. This suggests that, at the relevant stage, both languages underwent interference from Hebrew, but at the same time indicates that $\mathrm{P}-\mathrm{H}$ was not unknown to their previous history and maybe continued to exist in the colloquial usage. Interference from New Testament Greek cannot be ruled out, by contrast, for the Ancient Slavonic translation of the Bible, where one finds examples such as:

(i) Ancient Slavonic (Codex Zographensis, Matthew's Gospel, quoted in G.A. Khaburgaev, Staroslav'anskij jazyk. Moscow: Prosveščenije. 1974, p.419)

$\begin{array}{llllll}\text { Zane } & \text { ne } & \text { iměaxo } & \text { koreniě } & \text { i } & \text { isъxošę } \\ \text { since } & \text { NEG } & \text { have.IMPERF.3P } & \text { root.COLLECTIVE } & \text { and } & \text { wither.AOR.3P }\end{array}$

'Since they had no roots, they withered'.

As far as we know, and interestingly for our purpose, this fact is pointed out here for the first time. This shows that P-H has not attracted the specialists' attention beyond the domain of Romance linguistics.

As for Hebrew, one should consider that the wa coordinator was fairly frequently used to introduce a new proposition. It is therefore not easy to set apart true $\mathrm{P}-\mathrm{H}$ from the various sequences of coordinated propositions that might be understood (in textual semantics terms) as based on implicit hypotactic relations. See the discussion relative to the examples in (28). This often gave rise to ambiguous constructions, intermediate between parataxis and hypotaxis, although structurally different from actual P-H.
} 
2010, etc.). This may be the result of pragmatic intentions such as: (a) emphatic asseveration, as favored, e.g., by the semantic equivalence |et 'and' = etiam 'also'|, not infrequent in Latin (29); (b) emphatic contrast as in (30), which could easily translate into a hypothetical para-hypotactic structure of the type 'although X, but Y'; (c) emphatic stressing of an unexpected event or new development (31), frequently reinforced as in Lat. et ecce, It. ed ecco, Fr. et voilà (roughly translatable as: 'and suddenly').

Latin [Vulgata, Tim. 2 2.12]

$\mathrm{Si}$ negaveri-mus, et ille neg-ab-it nos

if deny.FUT.PERF-1P COORD DEM.NOM.MS deny-FUT-3S 1P.ACC

'If we deny him, he will deny us as well'

(30) Italian [Pulci, Morgante, 18, octave 196]

$S$, tu rid-i, ed io piang-o

if $2 \mathrm{~S}$ laugh.IND.PRES-2S COORD $1 \mathrm{~s}$ cry.IND.PRES-1S

'If you laugh, I cry' [= you laugh, but I cry]

(31) Italian [Boccaccio, Dec., IX,8]

e in_questo_che egli così si rodev-a, e

COORD while 3.MS so 3.RFL wear_out.PAST.IMPERF-3S COORD

Biondel venn-e

Biondel come.PAST.PERF-3S

'And while he was wearing himself out, Biondel came'

In all these examples the speaker appears to exploit the para-hypotactic coordinator in order to underline the emphatic import of the main clause. In addition, it should be remarked that a proleptic dependent clause often fulfills the pragmatic role of introducing a sentence topic (Haiman 1968), which in particular cases might turn out to be a true discourse topic. The interconnecting coordinators might thus be conceived of as sharing important features with those discourse markers which typically fulfill a rhetorical enhancing function. They can, e.g., be compared to then and yet in structures like: 'if / when $\mathrm{X}$, then $\mathrm{Y}$ ' or 'although $\mathrm{X}$, yet $\mathrm{Y}$ '. Indeed, the para-hypotactic coordinators are occasionally reinforced by true discourse markers, as in (32), featuring an Italian example from the end of the $13^{\text {th }}$ century.

$$
\begin{aligned}
& \text { Italian [Novellino, 41, 7-14] } \\
& \begin{array}{lllllllll}
\text { e } & \text { tuttoché } & \text { messere } & \text { Polo } & \text { foss-e } & \text { loro } & \text { maggiore } & {[\ldots]} & \text { ma } \\
\text { and } & \text { although } & \text { sir } & \text { Polo } & \text { be.SUBJ.IMPERF-3S } & \text { 3P } & \text { older } & & \text { but }
\end{array} \\
& \text { pure in quello luogo leggiadro non ardi-a sedere } \\
& \text { even/yet in that place nice NEG dare.IMPERF-3s sit_down.INF } \\
& \text { 'And although sir Polo was older than them, yet he did not dare to sit down in that nice }
\end{aligned}
$$

These two lines of explanation (syntactic and pragmatic) should not be viewed as orthogonal to each other. As a matter of fact, they are often invoked by one and the same author. The emerging 
of P-H may indeed be preceded by the frequent use of coordinating constructions which reduce the distance between parataxis and hypotaxis, while the coordinators introducing the main clause may express (or gradually develop) the rhetorical role of an emphatic discourse marker. The latter function may persist, due to normal communicative needs, even after P-H has become a conventionalized syntactic behavior, although at that stage this is no longer a precondition for its appearance.

\subsection{P-H and Processing Facilitation}

While this developmental path is perfectly reasonable, there are aspects which remain unaccounted for. In particular, why should the respective order of main and dependent clause be so rigidly determined, as repeatedly illustrated in this paper (namely: dependent clause + main clause) $?^{12}$ The textual rhetorical function pointed out above could in fact also be available to the reverse order, provided the appropriate prosodic cues be offered by the speaker (and supplied by the reader).

One hypothesis that comes to mind is that the para-hypotactic coordinators fulfill a demarcation function, in the same vein as the linguistic devices described by Heath (2010), such as: constituent order, boundary marking morphemes, continuous morphological indexation. What these devices have in common is their propensity to help the hearer parse the sentence into clauses: an important processing facilitation. P-H may be regarded as a fairly efficient device in this respect. In the Ayoreo oral texts, out of 26 proleptic dependent clauses, only 6 have no parahypotactic coordinator; furthermore, in 2 out of the 6 exceptions there is a heavy pause to mark the syntactic boundary, and in 2 additional cases a new subordinator follows, introducing another dependent clause. Excluding the just noted exceptions, it turns out that up to $92 \%$ of the proleptic dependent clauses are followed by a para-hypotactic coordinator (definitely a higher figure than the one provisionally reported at the end of $\S 4$ ).

Needless to say, the efficiency of $\mathrm{P}-\mathrm{H}$ as a demarcating device is not flawless, as the following examples from the Bible translation show. Sentence (33) features a sequence of two coordinators, giving rise to an ambiguous situation. The first enga might in fact wrongly be perceived as introducing a coordinated second member of the proleptic dependent clause, instead of the coordinated first member of the main clause. Example (34a) presents a high level of syntactic complexity, which preempts any possible parsing facilitation attached to the one and only para-hypotactic coordinator, for this can hardly be factored out from the other coordinators. To better illustrate this point, (34b) displays the structure of this sentence.

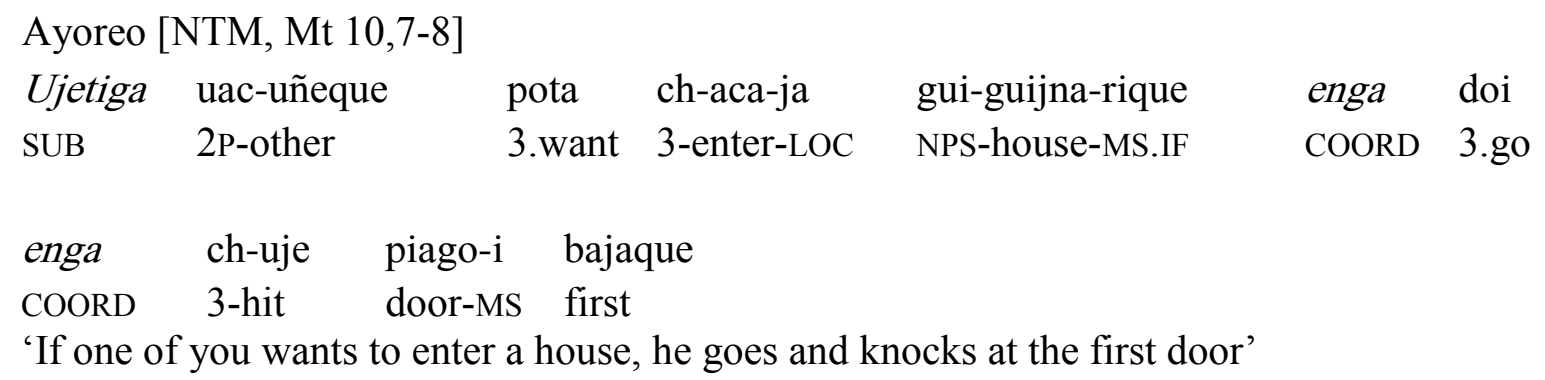

\footnotetext{
${ }^{12}$ We obviously neglect the mirror structure "COORD main clause SUB dependent clause", relatively frequent in both spontaneous and written texts, for the initial coordination is governed by completely different textualpragmatical motivations (cf. And then I suddenly left, because it was late).
} 
(34a) Ayoreo [NTM, Mt 10,28]

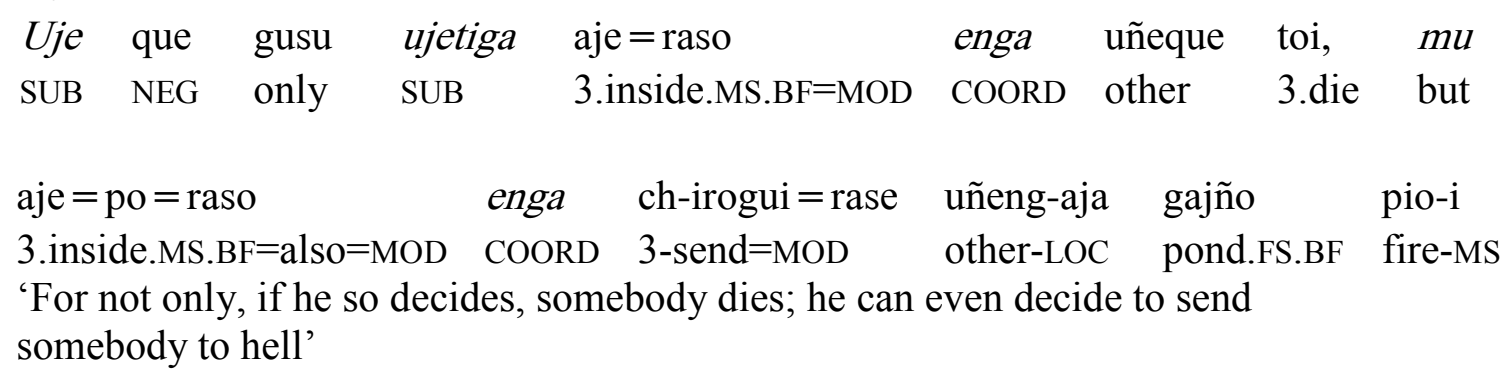

uje que gusu (negative discourse marker)

ujetiga (SUB) ajeraso (dependent clause)

enga (P-H COORD) uñeque toi (main clause)

$m u$ (adversative COORD, tied to the above discourse marker)

ajeporaso (dependent clause, with implicit SUB)

enga (P-H COORD) chiroguirase... (main clause)

Despite these limitations, the demarcation hypothesis retains its validity if one considers that: (a) the above sentences are admittedly more elaborate than most spontaneously produced ones (indeed, none of our oral texts reaches this level of syntactic elaboration); (b) in the cases at stake, each coordinator delimits the boundary of a proposition, even when it does not signal the actual boundary between dependent and main clause. Obviously, a coordinator can also occupy a clause-internal position (as when it connects two NPs), but this should not cause major processing difficulties.

Further and crucial support to the demarcation hypothesis derives from the prosodic component, at least as far as Ayoreo is concerned. As it happens, in the Ayoreo oral texts the para-hypotactic coordinators often precede the pause, rather than following it. The prospect below presents the relevant data stemming from the Ayoreo corpus used for this study: ${ }^{13}$

$$
\begin{aligned}
& \text { Relative position of coordinator and pause } \\
& \begin{array}{lcl}
\text { no pause pause }+ \text { coordinator } & \text { coordinator }+ \text { pause } \\
2 & 3 & 12 \text { (including concessives) }
\end{array}
\end{aligned}
$$

The relatively high frequency of pre-pausal coordinators suggests that they act indeed as syntactic boundary markers. This does not exclude that they also fulfill other textual-pragmatic functions, as suggested in $\S 5.1$, but strongly emphasizes that the latter cannot be their only function. This is confirmed by the occasional use of the Ayoreo coordinators in clause- or sentence-final position independently of $\mathrm{P}-\mathrm{H}$, as shown in the following oral text examples. In

\footnotetext{
${ }^{13}$ It should be remarked that in Old Romance edited texts the para-hypotactic coordinators usually follow a punctuation mark and in any case they never precede it. But since these texts underwent careful editing normalization, one cannot know for sure what was the exact prosodic use of the para-hypotactic coordinators in the oral language. At any rate, since P-H is also present in other modern languages, this hypothesis can be empirically and easily tested.
} 
both cases, the coordinator marks the end of the clause. ${ }^{14}$

Ayoreo [PREACHERS]

Y-uj-ode ayore-o uaque a uje uac-angureta-yo Dupade enga 1S-countryman-MP ayoreo-MP.BF 2P EPST SUB 2P-believe-2P God COORD 'My brothers who believe in God' [= My brothers, you who are people who believe in God]

$$
\begin{aligned}
& \text { Ayoreo [Samane] } \\
& \begin{array}{llll}
\mathrm{Mu} \quad \text { ore } \quad \text { ch-ajnesaru=rasu da-nir-one } & m u \\
\text { but } 3 \mathrm{P} & \text { 3-return=MOD } & \text { RFL-land-MP } & \text { but } \\
\text { 'But they would like to go back to their land' }
\end{array}
\end{aligned}
$$

It is worth repeating that the demarcating and the textual-rhetorical functions are not orthogonal. Indeed, the former function might be absent in specific languages, possibly having disappeared at some point. ${ }^{15}$

It is also important to observe that the demarcating function of the para-hypotactic coordinators presupposes, by its very nature, a right-branching syntactic orientation, with the subordinators in clause-initial position. The immediate question that arises is whether leftbranching languages, with clause-final subordinators, can present the symmetric analogue of $\mathrm{P}-\mathrm{H}$ - which might be called "anti-para-hypotaxis" - according to the following scheme (to be compared with [1]): ${ }^{16}$

$$
\text { main-clause }+ \text { COORD }+ \text { dependent-cause }+ \text { SUB }
$$

We offer this speculation for future research. Should such a structure exist, it would provide additional proof of the syntactic, rather than (strictly) pragmatic motivation of the construction at stake.

As a final observation, one might legitimately propose that $\mathrm{P}-\mathrm{H}$ is in complementary distribution with switch reference (or rather, "event (dis)continuation", to use a more comprehensive term). The basis of this observation is that both $\mathrm{P}-\mathrm{H}$ and event (dis)continuation fulfill a delimitative function. It is thus to be expected that they do not coexist.

\footnotetext{
${ }^{14}$ Incidentally, (36) exhibits one more example of implicit relative clause, like (19b).

${ }^{15}$ Bartolotta et al. (2011) provide evidence (with examples from Hittite, Vedic, Ancient Greek, Latin, Old Persian, Old Irish) suggesting that the ancient Indo-European languages presented a number of clause "introducers" which might have had a demarcating function, in addition to a textual-pragmatic one ("The function of these particles must have been to assure the connection between clauses and sentences and/or the cohesion of discourse", p.54). As the authors note, these connectors had a role in the development of hypotactic structures, by gradually changing their own syntactic role. Particularly interesting for our present concern is their example (14a), featuring the Hittite clause-initial connector $n u$ in a correlative construction (see $\S 5.1$ ) which seems to be a precursor of full-fledged P$\mathrm{H}$.

${ }^{16}$ Needless to say, as observed in fn. 2, anti-P-H might, just as P-H, might involve a dependent clause with a nonfinite verb form. What matters is the relationship of syntactic dependency, rather than the presence of an explicit subordinator.
} 


\section{Areality}

As noted at the outset, the exact geographical distribution of P-H is unknown. Until recently (cf. Rebuschi 2001; Bril \& Rebuschi 2006b), this kind of constructions had only been described for Old Romance and the Classical languages (including Biblical Hebrew). The discovery of P-H in the Zamucoan languages opens the door for a large scale investigation, which might produce surprising results. While conducting this research, one of the present authors launched a query on the web-forum "Etnolingüística", expressly devoted to South-American linguistics, asking for possible analogues in other languages of the continent. Two scholars provided immediate response: Alain Fabre, who mentioned Nivaclé (39), and Pedro Viegas Barros, who pointed out the data in (40-42). Further inspection into the grammar of other languages of the same area revealed that at least Mocovi should be added to the list. Apparently, P-H is not restricted to the Zamuco family, but seems to be an areal feature fairly wide-spread in the Chaco region.

(39) Nivaclé, Mataguayo (Fabre, p.c.)

$\begin{array}{lllll}\text { Meelhti } & \text { yi-na-jayan-taj } & p a & \text { lhechesh } & \text { lhôn } \\ \text { when } & \text { CONJ.IND.3A(3P)-bathe-CAUS-IRLS/DUR } & \text { COORD } & \text { then } & \text { EVID }\end{array}$

$\begin{array}{lll}\text { ti } & \text { yi-mac } & \text { lhôn } \\ \text { CONJ.IND } & \text { 3s-die } & \text { MED (hearsay) }\end{array}$

'When she bathed (the baby), he (the baby) died (was dying)'

(40) Maká, Mataguayo (Gerzenstein 1994:203, ex. [375])

In n-ikfel-ets n-e' Sara qa n-ayu-kii

SUB 3-know-POSTP DEM-F Sara COORD 3-get_angry-CLIT

'When Sara knew it, she got angry'

(41) Wichí, Mataguayo (Terraza 2009:247, ex. [49])

$\begin{array}{lllllll}\ldots \text { tox } & \text { imawu-p'ante } & \text { y-iq } & \text { wit } & \text { yux }^{\mathrm{w}} \mathrm{axk}^{\mathrm{w}} \mathrm{e} & \varnothing-\mathrm{nom} & \text { hayox } \\ \ldots \text { SUB } & \text { fox-TEMP } & \text { 3-go } & \text { COORD } & \text { fast } & \text { 3-come } & \text { jaguar }\end{array}$

'And when the fox goes, the jaguar comes fast'

(42) Pilagá, Guaycurú (Vidal 2001:369, ex. (14c))]

Qanče da' s-aqa-t-iyi so' biaSase-lo'ok qanč'e

COORD COMP 3-fill-ASP-DIR CL brown_deer-skin COORD

qo-yi-yamaSat qataSa qo-y-aw'o ke'ena

IS-3-get_toghether COORD IS-3-make añapa

'And when she fills the leather bag, then they get together (the women) and prepare ke'ena (=sp. of sweet drink “añapa”)'

(43) Mocoví, Guaycurú (Grondona 1998:169, ex. [364])

No?om yaGat $k a$ ? sqae-s-ik

if rain COORD NEG-1AC-go

'If it rains, I do not go' 
This opens an interesting scenario. Indeed, the historical and cultural data indicate that the Zamucoan people - especially the Ayoreos, who remained virtually uncontacted until recently did not entertain strict relationships with the adjacent ethnic groups. Yet, their syntax shares a distinctive feature with other Chaco languages, which are otherwise very different in many structural and typological respects. Should this be due to reciprocal influence, it would suggest that the interethnic contacts were much more intense than usually assumed. The alternative consists in assuming that $\mathrm{P}-\mathrm{H}$ is a very old trait, dating back to a time in which the antecedents of the present ethnic groups still had relatively intense cultural exchanges. ${ }^{17}$

One hint in that direction is the presence of P-H in Iquito, a Zaparoan language of northern Peruvian Amazonia. The relevant examples can be found in a paper by Lev Michael, included in the collection by Dixon \& Aikhenvald (2009). This author does not use the term P-H, nor is this syntactic feature mentioned in the introduction by R.M.W. Dixon, nor in the concluding remarks by Alexandra Aikhenvald, despite the wealth of observations that both contributions offer. Actually, the focus of this collection is on the semantics (rather than syntax) of clause linking, but in any case this is further indication that P-H has so-far escaped general attention. Yet, the examples in Michael (2009) are compelling, as the following quotation shows:

Iquito, Zaparoan (Michael 2009:153, ex. [5])

$\begin{array}{lllll}\text { Jiticari } & \text { taa } & \text { jahuana } & \text { nasi }=n a & \text { quia }=\text { nu }=1 \text { ituu- } \varnothing \\ \text { when } & \text { COP } & \text { dry } & \text { swidden }=\text { na } & 2 \mathrm{SG}=3 \mathrm{SG} . I R R=\text { burn-PERF }\end{array}$

'When the swidden is dry, you will burn it'.

As Michael states:

An extrametrical clause-final clitic $=n a$ is associated with boundaries between fully inflected subordinate clauses and main clauses. This clitic appears at the end of a fully inflected subordinate clause if it is followed by material from the main clause [...]. Note that clauses with nominalized main verb never bear this clause-final clitic. (Michael 2009:151)

The final part of this quotation is revealing: when the main clause contains a feature that automatically distinguishes it from the proleptic dependent clause, the $=n a$ demarcator is no more needed. ${ }^{18}$

\footnotetext{
${ }^{17}$ The further hypothesis, pointing to a possible common genealogical derivation of the Mataguayo, Guacurú and Zamucoan languages, should best be discarded. First, it would be rather surprising that precisely P-H were among the very few morpho-syntactic features still shared by these language families. Second, the recent investigation by Müller et al. (2010) shows that the separation of Zamuco from the surrounding families must be very old. As it happens, this family does not seem to present any noticeable analogy with any other South-American family. The fact that in Müller et al.'s analyses Ayoreo and Chamacoco show some affinity with Papuan languages simply means that they are an absolute isolate, for such distant relationships can only be interpreted as mere coincidence.

${ }^{18}$ Note that the situation described by Michael for Iquito differs from the one depicted in $\mathrm{fn}$. 2 for the ancient Romance languages, where even proleptic dependent clauses with non-finite verb could yield P-H.

Among the examples with proleptic dependent clause reported by Michael, ex. (16) p.156 seems to constitute an exception. However, the proleptic conditional clause ends with the word masiáana 'many', which is itself closed by the syllable $n a$, and the following word - the first of the main clause - begins once again with the same syllable ( $n a=$ masicatataa 'they break the limbs (imperf)'). One might thus surmise that the insertion of $=n a$ is prevented by some sort of haplology.
} 
The Iquito case demonstrates that the P-H distribution area is certainly larger than the Gran Chaco region. This invites further inquiry into the languages spoken in South-America. On a larger scale, the question waiting for an answer is how much P-H (or, possibly, anti-P-H) is present in other parts of the world. The Swahili case reminds us that it is indeed documented in other linguistic areas. Not infrequently, a given phenomenon fails to be mentioned in grammatical descriptions until somebody points it out. This was one further motivation to write this paper.

\section{Abbreviations}

A: agent; ABL: ablative; AC: active; ACC: accusative; AGENT: agentive; AOR: aorist; APPL: applicative; ASP: aspect; BF: base-form; CAUS: causative; CLIT: clitic; CL: positional/deictic_classifier; COMP: complementizer; CONJ: conjunction; COORD: coordinator; DEM: demonstrative; DET: determiner; DIR: directional_suffix; DO: direct object; DUR: durative; EMPH: emphatic; EPST: epistemicity; EXIST: existential; EVID: evidentiality; FUT: future; GEN: genitive; GER: gerund; IF: indeterminate-form; IMPERF: imperfect; IND: indicative; INF: infinitive; INTERJ: interjection; IRLS: irrealis IS: impersonal_subject; ITER: iterativity; LOC: locative; M: masculine; MOD: modality; NEG: negation; NOM: nominative; NPS: non-possessable; OBJ: object; P: plural; PE: plural_exclusive; PI: plural_inclusive; PAST: past; PERF: perfect; POSTP: postposition; PRES: present; RFL: reflexive; s: singular; SUBJ: subjunctive; SUB: subordinator; TEMP: temporal_marker

\section{References}

Abeille, Anne \& Robert Borsley. 2006. La syntaxe des corrélatives comparatives en anglais et en français: Faits de Langues, in Bril \& Rebuschi 2006a, 21-33.

Bartolotta, Annamaria, Emanuele Lanzetta \& Lucio Melazzo. 2011. Wh-Relative Clauses and Left Periphery from Latin to some Romance Languages. International Journal of Diachronic Linguistics and Linguistic Reconstruction 8.43-87.

Bertinetto, Pier Marco. 2009. Ayoreo (Zamuco). A grammatical sketch. Quaderni del Laboratorio di Linguistica della Scuola Normale Superiore 8 n.s. $<$ http://linguistica.sns.it/QLL/QLL09/Bertinetto_1.PDF $>$

Bickel, Balthasar 2010. Capturing particulars and universals in clause-linkage. A multivariate analysis: Clause linking and clause hierarchy: syntax and pragmatic, ed. by Isabelle Bril, 51101. Amsterdam/Philadelphia: John Benjamins.

Bril, Isabelle \& Georges Rebuschi, eds. 2006a. Coordination et subordination: typologie et modélisation. Faits de Langues, Revue de Linguistique 28. Paris: Ophrys.

----. 2006b. Coordination, subordination et co-jonction. Faits linguistiques et concepts: Faits de Langues, in Bril \& Rebuschi 2006a, 7-20.

Ciucci, Luca. 2010. La flessione possessiva del chamacoco. Quaderni del Laboratorio di $\begin{array}{llllll}\text { Linguistica della Scuola Normale } & \text { Superiore } & 9 / 2 & \text { n.s. }\end{array}$ $<$ http://linguistica.sns.it/QLL/QLL10/Ciucci_chamacoco.pdf>

Note also that -na occurs only when the proleptic clause is syntactically dependent, not just a semantically "supporting clause", as defined in Dixon \& Aikhenvald collection. This is shown by example (18), introduced by an implicit counterfactual conditional. Supposedly, prosody supplies the relevant boundary signal in such cases. 
Chomé, Ignace (S.J.). 1958 [before 1745]. Arte de la lengua zamuca. Présentation de Suzanne Lussagnet. Journal de la Société des Américanistes 47.121-178.

Dixon, Robert M.W. \& Alexandra Y. Aikhenvald, eds. 2009. The Semantics of Clause Linking. A Cross-linguistic Typology. Oxford / New York: Oxford University Press.

Durante, Marcello. 1982. Dal latino all'italiano moderno. Bologna: Zanichelli.

Fischermann, Bernd. 1988. Zur Weltsicht der Ayoréode Ostboliviens. Bonn: Rheinische Friedrich-Wilhelm-Universität.

Foley, William A. \& Robert D. Van Valin Jr. 1984. Functional syntax and universal grammar. Cambridge: Cambridge University Press.

Friedmann, Naama \& João Costa. 2010. The child heard a coordinated sentence and wondered... Lingua 120/6.1502-1515.

Gerzenstein, Ana. 1994. Lengua Maká. Estudio descriptivo. Buenos Aires: Universidad de Buenos Aires, Facultad de Filosofía y Letras, Instituto de Lingüística.

Grondona, Verónica María. 1998. A Grammar of Mocoví. Ph.D. dissertation. Pittsburgh: University of Pittsburgh.

Heath, Jeffrey. 2010. Typology of clausal boundary marking devices. Linguistic Typology 14/1.127-151.

Higham, Alice, Maxine Morarie \& Greta Paul. 2000. Ayoré-English dictionary, 3 tomos. Sanford, FL.: New Tribes Mission.

La Fauci, Nunzio. 1978. Note per una grammatica della replica. Linguistica e Letteratura 3/1.939.

Lehmann, Christian. 1988. Towards a typology of clause linkage: Clause combining in grammar and discourse, ed. by John Haimann \& Sara A. Thompson, 181-225. Amsterdam: Benjamins.

Mazzoleni, Marco. 2002. La "paraipotassi" con ma nell'italiano antico: verso una tipologia sintattica della correlazione. Verbum 4/2.399-427.

Michael, Lev. 2009. The semantics of clause linking in Iquito: The Semantics of Clause Linking. A Cross-linguistic Typology, ed. by Robert M.W. Dixon \& Alexandra Y. Aikhenvald, 145166. Oxford / New York: Oxford University Press.

Müller, André, Søren Wichmann, Viveka Velupillai, Cecil H. Brown, Pamela Brown, Sebastian Sauppe, Eric W. Holman, Dik Bakker, Johann-Mattis List, Dmitri Egorov, Oleg Belyaev, Robert Mailhammer, Matthias Urban, Helen Geyer \& Anthony Grant. 2010. ASJP World Language Tree of Lexical Similarity: Version 3 (July 2010). $<$ http://email.eva.mpg.de/ wichmann/language_tree.htm>

NTM = New Tribes Mission. 1982. Dupade Uruode. Cochambamba.

Pasquali, Giorgio. 1929. Le origini greche della paraipotassi romanza. Atene e Roma 10.116-119 (also in Id.: Lingua nuova e antica. Firenze, 1964).

Preachers $=$ Internet sermons. A collection of texts of religious content downloadable at: $<$ http://globalrecordings.net/langcode/ayo $>$

QCCB = Briggs, Janet. 1972-1973. Quiero contarles unos casos del Beni. 2 vols. Cochabamba: Instituto Lingüístico de Verano en colaboración con el Ministerio de Educación y Cultura, Dirección Nacional de Antropología.

Rebuschi, Georges. 2001. Coordination et subordination. Première partie: la co-jonction restreinte. Bulletin de la Société de Linguistique de Paris 96.23-60.

---- . 2002. Coordination et subordination. Deuxième partie: vers la co-jonction généralisée. Bulletin de la Société de Linguistique de Paris 97.37-96. 
Rotaetxe, Karmele. 2006. A mi-chemin entre la coordination et la subordination. L'enclitique basque -(e)ta: Faits de Langues, Revue de Linguistique 28, ed. by Isabelle Bril \& Georges Rebuschi, 215-230. Paris: Ophrys

Salvi, Giampaolo \& Lorenzo Renzi. 2010. Grammatica dell'Italiano Antico. Bologna: Il Mulino. Sorrento, Luigi. 1929. Il fenomeno della paraipotassi nelle lingue neolatine. Rendiconti del Reale Istituto Lombardo di Scienze e Lettere 52/11.449-463.

----. 1950. La paraipotassi, in: Id., Sintassi romanza. Ricerche e prospettive, 25-91. VareseMilano: Sozzi.

Torterat, Frédéric. 2000. Et en emploi 'syndético-hypotactique': hypothèse sur une jonction implicite en ancien et en moyen français. Bulletin de la Société de Linguistique de Paris 95.183-202.

Terraza, Jimena. 2009. Grammaire du wichí: Phonologie et Morphosyntaxe. Thèse de Doctorat en Linguistique. Montreal: Université de Québec à Montreal.

Ulrich, Matthew \& Rosemary Ulrich. 1992. Génesis en Chamacoco. Asunción: New Tribes Mission.

-----. 2000a. Porrosht Ahwoso Ahlo ishir Ahwoso. Nuevo Testamento en Chamacoco. Asunción: New Tribes Mission.

-----. 2000b. Diccionario Ishiro (Chamacoco) - Español / Español - Ishiro (Chamacoco). Asunción: New Tribes Mission.

Vidal, Alejandra. 2001. Pilagá Grammar (Guaykuruan Family, Argentina). Ph.D. dissertation. Eugene: University of Oregon.

---- . 2002. Oraciones complejas en pilagá (guaycurú): Temas de Lingüística Aborigen II, ed. by Ana Fernández Garay \& Lucía Golluscio, 161-187. Buenos Aires: Universidad de Buenos Aires, Facultad de Filosofía y Letras, Instituto de Lingüística.

Wehr, Barbara. 1984. Diskurs-Strategien im Romanischen. Ein Beitrag zur romanischen Syntax. Tübingen: Gunter Narr.

Authors' Contact Information:

Pier Marco Bertinetto

mbertinetto@sns.it

Luca Ciucci

1.ciucci@sns.it 